Dominik Tomczyk Sch. P.

\title{
KRĄG BIBLIJNY
}

Egzegetycznej literatury fachowej jest dość, szczególnie na Zachodzie Europy, lecz nadal brakuje praktycznych wskazań do prowadzenia grup biblijnych. Nie chodzi przy tym o wprowadzającą teorię, ale o rzeczywiście praktyczne światło takiej pracy w grupach. Życzenie takie jest bardzo aktualne w związku z tymi, którzy są zainteresowani spotkaniem z Bogiem poprzez Pismo św.

We współczesnym Kościele, dzięki odnowie soborowej, obserwuje my powstawanie wielu ruchów młodzieżowych, grup spontanicznycł czy też wspólnot nowego życia. Wśród nich tworzone są żywe kręgi biblijne. Myślę tu szczególnie o ruchu oazowym i charyzmatycznym na terenie naszego kraju. Spotkamy się u nich z medytacją religijna Słowa Bożego jako istotnego przyczynku do wewnętrznej odnowy życia. Dlatego możemy mówić o „nowym z zwrocie" w stronę spotka. nia z Biblią.

\section{NOWE TENDENCJE.}

Zasadniczo są dwie główne tendencje tego „biblijnego zwrotu”:

- nie chodzi tak bardzo o indywidualne czytanie Pisma św., lecz bardziej o zajmowanie się Biblią w grupie.

- Nie zmierza się do egzegetycznego poznania Bożego słowa jako „,studium dla studium”, ile raczej kładzie się nacisk na ujęcie życiowego znaczenia Pisma św. dla pogłębienia osobistej wiary.

To, że Bóg chce dzisiaj mówić i wzywać nas poprzez słowo swego Pisma, które jest słowem przemieniającej siły, służącej wewnętrznemu rozwojowi czytającego; to, że Bóg przede wszystkim oczekuje odpowiedzi na swój apel skierowany do serca człowieka i na inspirację modlitwy, na podjęcie takiego a nie innego działania - sa to podstawowe myśli tego zwrotu ku Bożemu Słowu.

\section{SZANSA NA DZIŚ - BOŻE SIOWO.}

Obok prywatnego czytelnika Pisma św. zauważa się czytanie wspólnotowe, odbywające się w wielu powstających, bądź powstałych kręgach biblijnych, grupach modlitewnych itp. $Z$ pewnością nie stanowi to jakiegoś modnego kierunku. Wypływa bowiem $z$ wielu przyczyn. Oto kilka z nich:

- $w$ rozmowie $z$ innymi nie naraża się człowiek na niebezpieczeństwo indywidualizmu w tłumaczeniu Pisma. Odczytujemy wtedy całą głębię Bożego Słowa od miłosierdzia, przez groźbę zniszczenia aż do apelu o współczłowieczeństwo. 
- Różnorodne zawody i powołania, z których wywodzą się uczestnicy spotkań, wnoszą bogactwo swego życia, poszerzają horyzonty poszczególnych osób wskazując, jak dany tekst biblijny mówi o każđorazowym wymiarze życia człowieka.

- Także istota człowieka i wiary staje się bliższa czlowiekowi przez światło Słowa natchnionego. Poznanie własnego życia uzyskujemy przez obcowanie $z$ innymi, przez wymianę myśli itp. Każdy wierzący jest w gruncie rzeczy współwierzącym - każdy wierzy $z$ innymi, tj. jest ożywiany przez wiarę innych. Nie ma prywatyzacji wiary jako wyłącznie mojej sprawy. Ta podstawowa rzeczywistość Iudzkiego kontaktu wychodzi naprzeciw rozważaniu Pisma św. w grupach.

- Izolacja, w którą czlowiek jest zaplątany, zostaje przełamana przez społeczność grupy. Po krótkim okresie czasu powstaje bowiem w grupie atmosfera otwarcia i wzajemnego przyjęcia. Często wyrasta to na bazie wzajemnego słuchania i mówienia o doświadiczeniu Słowa Bożego. Uczestnicy odczuwają prawdziwą więź rodzinną.

-.-Wiele asób odnajduje siebie w grupie, swoją odwagę, pociechę dla siebie $\mathrm{i}$ swych religijnych przekonań i doświadczeń. Początkowe zahamowania, poprzez dyskrecję innych, zostaja powoli przełamywane w cieple Bożego Słowa.

- Wypowiadanie się o rzeczach wiary daje pole refleksji i wzajemnego zbliżenia. Człowiek dzieli się z drugim człowiekiem czymś wspólnym, tj. swoją wiarą i doświadezeniem Boga. To pomaga, by stać sic aktywnym w rodzinie, w kręgu znajomych czy w miejscu pracy.

\section{WKŁAD KAŻDEGO JEST WAŻNY.}

Pierwszą prawdą, jaką przyjmuje się $\mathrm{w}$ spotkaniach' $z$ Biblią, jest ta, że każdy wierzący jako ochrzczony chrześcijanin jest prowadzony przez Ducha Swiętego (1J 2, 27), że każdy przeżył już jakieś własne doświadczenie wiary i życia i że chce je przekazywać dalej dzieląc sie nim $z$ innymi. Każde takie świadectwo jest ważne, służy bowiem ku zbudowaniu w.szystkich.

Oprócz własnego wkładu kształtującego obraz spotkań biblijnych, członkowie grup winni nadsłuchiwać, co mają do powiedzenia egzgecibibliści w danej kwestii. Naturalnie, egzegeza ma swoje znaczenie i byłoby czymś fatalnym, gdyby Biblia była czytana i rozumiana literalnie, doslownie. Byłoby to czytanie naiwne, wprowadzające więcej chaosu niż radości ze spotkania Boga w Slowie. Byłaby to niepotrzebna sprzeczność pomiędzy myślą człowieka a jego wiarą. Dlatego w wielu takich problemach, gdzie rozum ludzi nie może dać odpowiedzi właściwej, pomaga egzegeza. Rozwiązuje ona problemy rozu- 
mienia Pisma św. przez podanie Sitz im Leben oraz Formgeschichte danego tekstu biblijnego. Jej zadaniem jest bowiem przybliżenie ludziom treści słowa natchnionego.

\section{POWSTAWANIE GRUPY.}

Życzenie spotkania z Biblia jest czymś, co urzeczywistnia życzenie innych. Każdy początek jest trudny, ale dzięki radosnemu pragnieniu i ufności $w$ to, że Bóg chce, byśmy spotkali się z Nim w Jego Słowie; wszystko powoli stawać się będzie coraz jaśniejsze i prostsze.

$\mathrm{Na}$ początku winniśmy szukać tego, który mógłby poprowadzić spotkania w grupie kręgu biblijnego. Może nim być proboszcz danej parafii, który dawałby pewne impulsy grupie przez głoszenie słowa lub też przez dzielenie się doświadczeniami własnej pracy duszpasterskiej na kanwie Bażego Słowa. Winien to być przede wszystkim czlowiek, który zna i kocha Biblię. Pozwala on zrozumieć dany tekst Biblii. Może to uczynié przez 15-minutowy wykład, jako podanie nowych informacji o dzisiejszym rozumieniu danego fragmentu Fisma św., pozostawiając na boku trudności historyczne formowania się dzisiejszego spojrzenia na dany tekst.

Ważne przy tym jest zastosowanie praktycznej metody wykorzystywanej przez prowadzącego spotkania w grupach. Metoda bądź metody mają być przede wszystkim pomocnymi drogami, prowadzącymi do zamierzonego celu. Dzięki zastosowaniu i użyciu odporwiednich metod wcześniejsze doświadczenia członków spotkań mogą zostać pogłębione przez obecne doświadczenia Slowa Bożego. Właściwymi metodami nie są więc te, które nie pasują dla wiszystkich tekstów biblijnych, oraz te, które nie zawsze prowadzilyby do osiagnięcia zamierzonego celu. Metoda winna byé uniwersalna w swym zastosowaniu, tzn. dająca się wykorzystaé do rozwiązywania trudnych kwestii większości tekstów.

\section{PROWADZENTE ROZMÓW.}

Prowadzacy spotkania biblijne winien przyswoić sobie pewne reguły prowadzenia rozmów, które podane zostaną przy końcu naszych rozważań.

„Czytać Biblię - ale jak?" - jest to podstawowe wyjściowe pytanic dla kręgu biblijnego. W odpowiedzi winno sie nie tylko podawać wprowadzajace informacje do czytania, ile prizede wszystkim ukazywać pomocność Biblii dla pogłębienia doświadczenia wiary własnego życia z Bogiem poprzez kontakt ze Słowem Bożym.

Pierwsze spotkanie wydaje się zarówno dla prowadzącego jak i dla uczestników najtrudniejszym. Potrzeba zatem jakby szczegóko- 
wego jego opisu. Uczestnicy spotkania, kręgu, wspólnaty, grupy nie znają się jeszcze wzajemnie, sama rzecz spotkania jest im oboa, odległa, spotykamy bojaźń, ewentualną niepewność odnośnie sensu pobytu na takim spotkaniu, różnice temperamentów, zawodów, uczuć, wewnętrznych pytań itp.

Musimy pamiętać, szczególnie przy pierwszym spotkaniu, że punktem centralnym kręgu biblijnego nie jest sam temat spotkania, ale c złow i e k. Zarówno niepewność, jak i atmosfera wzajemnego przyjęcia jest czymś konstruktywnym dla przebiegu i wzrostu kręgu biblijnego. Uczestnicy bowiem poznają się wzajemnie, wyrażają swe oczekiwania pod adresem spotkania, podają uwagi dotyczące formy, przebiegu czy całokształtu spotkań, wytyczają odpowiadający im „,kurs" spotkań biblijnych.

Wtedy też krąg biblijny zawiązuje się sam w sobie. Głównym celem pierwszego wieczoru jest więc stworzenie odpowiedniej atmosfery, wyjaśnienie cczekiwań i rozwiązanie obaw oraz danie przedsmaku prawdy Bożego Słowa.

\section{PRZEBIEG SPOTKANIA.}

W naszych spotkaniach $z$ Biblią nie chodzi $w$ pierwszej linii o jakieś egzegetyczne dyskusje, ile raczej a wspólne czytanie Słowa w utworzonym kręgu biblijnym, by właśnie przez wspólnotę Słowa zbliżyé się do Boga, od którego ono wyszło i do którego ono prowadzi czytających. Celem jest dzielenie się swoją wiarą opartą na przeżywaniu Pisma św.

Przebieg spotkania może mieć następujący schemat:

1. Pozdrowienie. 2. Przedstawienie tekstu biblijnego do rozważania. 3. Wykład tekstu. 4. I rozmowa w małych grupkach. 5. I plenum dzielenie się odkryciem prawdy w rozważanym tekście. 6. Ewentualna przerwa (ok. 10 min.). 7. Krótka egzegeza tekstu (właściwe wyjaśnienie ważniejszych słów, etymologia, kontekst itp.). 8. II rozmowa w małych grupkach. 9. II plenum. 10. Modlitwa w oparciu o podany tekst. 11. Wnioski końcowe.

\section{MODEL ROZMOWY.}

Teoretycznie można opisać go w trzech zdaniach:

- każdy uczestnik zwraca uwagę na wrażenia, myśli i oczekiwania, które rodzą się mu przy podanym temacie, które następnie może uzewnętrznić;

- każdy respektuje równe prawa innych;

- każdy zajmuje się - na swój sposób - tematem. Grupa bowiem ma wspólny przedmiot rozważania. 
Strona praktyczna natomiast zawiera 10 punktów, które czynią rozmowę elastyczną a zarazem uporządkowaną.

Oto one:

1. Ustal kiedy chcesz zabierać głos, kiedy zaś nic nie mówić. Każdorazową chęć zabrania głosu zaznaczaj przez podniesienie ręki.

2. Mów w formie „ja" (1 os. sing.), nie używaj zaś formy ,my” (1 os. pl.)lub formy bezosobowej.

3. Mów z otwartością przy dzieleniu się swoimi myślami.

4. Nie krępuj się, jeżeli nie chcesz brać udziału w rozmowie.

5. Jeżeli chcesz o coś spytać, wyjaśnij krótko o co ci chodzi w pytaniu. Same tylko pytania działają często destruktywnie.

6. Nie zabieraj głosu, gdy mówi inna osoba.

7. Unikaj rozmów „na stronie”, tylko z poszczególnymi osobami.

8. Zwróć uwagę na zewnętrzne symptomy odbierania Bożego Słowa, tak u siebie, jak i u innych.

9. Miej poczucie tolerancji wobec innych.

10. Dyskretnie ochraniaj tajemnicę tego, co się dzieje w grupie.

Pismo św. jest słowem Boga skierowanym do czlowieka. W nim człowiek spotyka Boga poprzez Słowo Wcielone, które stało się Ciałem. Powstające grupy czy też kręgi biblijne, rozważające to spotkanie z Bogiem w Słowie, są wielką nadzieją dla współczesnego Kościoła. Potrzeba zatem otwartych serc naszych duszpasterzy by ci, którzy odczuwają głód Słowa Bożego, zostali w pełni zaspokojeni poprzez głębokie a zarazem religijne przeżywanie Pisma św. jako odkrywanie wciąż na nowo zawartej w nim prawdy o Bogu i o czlowieku.*

Kraków

DOMINIK TOMCZYK Sch. P.

* Opracowano na podstawie: „Bibel heute” 18 (1983) z. 74. 